\title{
The Council of Australian Government Reforms [2007-2013]: a critical juncture in Australian early childhood education and care (ECEC) policy?
}

Helen Logan", Jennifer Sumsion and Frances Press

* Correspondence: hlogan@csu.edu.au Charles Sturt University, Panorama Avenue, Bathurst, NSW 2795, Australia

\begin{abstract}
Between 2007 and 2013, the Council of Australian Governments (COAG) introduced major national policy reforms to improve quality in early childhood education and care (ECEC) (Brennan and Adamson, 2014). By analysing policy documents underpinning the COAG reforms for early childhood, this article contends these reforms have been so far-reaching that, conceivably, they could have a lasting impact on systems and structures designed to improve quality in ECEC and fundamentally alter the trajectory of future policies. To this extent, they could eventually prove to constitute a critical juncture (Hogan and Doyle 2009; Pierson, Politics in time: history, institutions, and social analysis, 2004) in Australian ECEC policy history. In this article, we speculate about whether history will position the COAG reforms as a critical juncture in policy or see them weakened by policy moves that erode provision of quality in ECEC. We argue that studying the potentiality of critical junctures in ECEC policy illuminates the complexity of policy production and provides insights into the nature of future policies.
\end{abstract}

Keywords: Council of Australian Governments (COAG) reforms; Critical juncture; Policy change; Quality; Discourse; Qualified staff

\section{Background}

Between 2007 and 2013, the Council of Australian Governments (COAG) introduced major national policy reforms to improve quality in early childhood education and care (ECEC) (Brennan and Adamson 2014). The COAG reforms for early childhood, hereafter referred to as the reforms, promised substantial financial commitment and legislative initiatives to improve early childhood outcomes for all Australian children. Initiatives included a National Partnership agreement across Australia's six States and two Territories for a National Quality Agenda to unify previously disparate State and Territory licensing and regulatory systems. The reforms included the following: stronger standards, streamlined approaches to regulatory requirements, a new rating system to measure quality, the first national ECEC curriculum document-the Early Years Learning Framework (EYLF), and strategies to develop the early childhood workforce (Council of Australian Governments 2009). In this context, the reforms aimed to improve quality by investing $\$ 77$ million over four years (Rudd and Macklin 2007b). This funding and changes to standards and

(C) 2015 Logan et al. This is an Open Access article distributed under the terms of the Creative Commons Attribution License (http:// creativecommons.org/licenses/by/4.0), which permits unrestricted use, distribution, and reproduction in any medium, provided the original work is properly credited. 
structures for the early childhood sector constituted "bold and ambitious" policy developments (Tayler 2011, 223). Yet the approach to government funding remained largely the same that tied government subsidy to systems that measure and monitor quality.

The ensuing National Quality Framework (NQF) aligns Australia's ECEC standards more closely with research evidence concerning the structural components of quality likely to improve child and family outcomes (Organisation for Economic Co-operation and Development 2006; Organisation for Economic Co-operation and Development 2012). At the time of writing, however, the Productivity Commission, the Australian Government's independent research and advisory body, has been commissioned to undertake an inquiry into the sustainability of Australia's ECEC system. While the Government's final report is still to be released, recommendations from the Draft Report into Childcare and Early Childhood Learning (Productivity Commission 2014) indicate that future policy directions for ECEC remain uncertain. In this article, we speculate about whether history will position the COAG reforms as a critical juncture or see them weakened by policy moves that erode provision of quality in ECEC, for example, through weakening standards for ECEC services. Our speculations are informed by findings from a study, currently underway, that investigates constructions of quality in Australian ECEC policy between 1972 and 2009. We focus specifically on an analysis of policy documents and interviews with key policy actors that have underpinned the COAG reforms for early childhood.

The article proceeds in four sections. First, for readers unfamiliar with contemporary Australian ECEC policy, we briefly outline the context of the COAG reforms. Second, we explain our understandings of critical junctures as important moments in policy development that radically alter the trajectory of policy (Pierson 2004) and produce "overwhelming mandates for policy and/or structural change" (Hogan and Doyle 2009, 213). Third, we briefly outline the study that has informed our speculations, with particular reference to a component of the study that involved the analysis of the COAG reforms. Fourth, we discuss the findings of our analysis which identify that the COAG reforms play a role in constructing quality in ECEC, primarily through discourses of investment in stronger standards and qualified staff. We conclude that sustaining the provision of quality is subject to political and ideational change, particularly in relation to key components of quality such as qualified staff and sustaining a skilled early childhood workforce.

\section{The Council of Australian Government Reforms for ECEC [2007-2013]}

The COAG, originally established in 1992, is a peak forum comprising ministerial members from each tier of Australian government: Commonwealth, States and Territories, and Local Government (Flottman and Page 2012). Responsibility for various aspects of Australia's ECEC system is shared between these tiers of government. For a decade or so prior to the reforms, national reports (Press and Hayes 2000; Elliott 2006; Press 2006) and international reports (Organisation for Economic Co-operation and Development 2006; United Nations International Children's Emergency Fund 2008) highlighted at least three key issues for Australian ECEC: fragmented and inequitable provision of existing policies and regulatory requirements, low levels of government investment compared to international standards, and increased reliance on markets and market mechanisms for the provision of services. These reports along with a growing body of evidence (Organisation for Economic Co-operation and Development 2006) 
identified the importance of access to quality in ECEC for improved child outcomes and raised concerns about the effectiveness of Australia's existing ECEC systems. Together, these reports and concerns provided a compelling platform for radical ECEC policy change.

The reforms, summarised in Appendix 1, were formalised in the National Early Childhood Development Strategy (the Strategy) (Council of Australian Governments 2009). The key to the reforms was a focus on quality as a centrepiece of change to systems and structures for the early childhood sector (Cheeseman and Torr 2009; Logan et al. 2012). In the following section, we elaborate on our understandings of how transformative policy change occurs and can be conceptualised as a critical juncture.

\section{Conceptualising critical junctures}

Critical junctures proffer explanations for major institutional and policy reform (Hogan and Doyle 2007). The study of critical junctures and related concepts of path dependency are crucial to understanding temporal processes of institutional change but have received less attention in relation to policy change (Pierson 2004). Critical junctures not only contribute to understandings of how policy change is connected to past events but can also provide enriched explanations of future policy directions.

Studies drawn from macro-economic and social policy (see for example, Donnelly and Hogan 2012; Gal and Bargal 2002; Hogan and Doyle 2007, 2009) describe elements that constitute critical junctures as eventuating at times of political, social or economic crises (Capoccia and Kelemen 2007; Hogan and Doyle 2007, 2009; Pierson 2004); a major digression (Gal and Bargal 2002) or "ideational and radical change" from previous policy (Hogan and Doyle 2007, 884); and having "lasting impact on subsequent decisions and structures" (Gal and Bargal 2002, 432). These studies have employed diverse approaches for examining critical junctures.

More recently, Hogan and Doyle (2009) developed a comparative framework for the study of critical junctures. They argue that ideational change is a crucial element that differentiates a critical juncture from less transformative policy change. In doing so, they contend that contextually specific factors, such as the influence of policy actors, play a role in bringing about ideational change.

If a critical juncture is indicated by lasting impact, at what point can the longevity of impact be determined? According to Donnelly and Hogan (2012), this lasting impact might be determined as a period beyond at least one change of government. Therefore, by providing a more contemporaneous timeframe, the transformational impact of policy change can be assessed within a defined period (Donnelly and Hogan 2012).

In our earlier writing, we conceptualised a critical juncture as requiring the presence of at least three key elements: political upheaval, a major digression from previous policy and lasting impact (Logan et al. 2013). However, in this article, we remould our previous conceptualisation to include a focus on ideational change (Hogan and Doyle 2009) and re-define our understanding of lasting impact to endure beyond at least one change of government (Donnelly and Hogan 2012). Similarly to Hogan and Doyle (2009), we suggest that when contextually specific factors of social, economic or political crisis, radical change and lasting impact are characterised by ideational change, they can 
signal a paradigm shift (Hall 1993), thereby constituting a critical juncture. In the following section, we elaborate on our methodology that draws on our current conceptualisation of critical junctures and combines this conceptualisation with an analysis of discourses that construct meanings within policy texts underpinning the COAG reforms. Partly, as a consequence of these discourses, new systems and structures construct quality in ECEC in complex ways.

\section{Methods}

\section{Methodology guiding the analysis}

To better understand the complexities of policy change, we turn our attention to discourses contained within policy texts. In doing so, we draw on Foucauldian perspectives of discourse $(1972,2000)$. Foucault $(1972,90)$ explains that discourse is "the general domain of all statements, sometimes as an individualizable group of statements, and sometimes as a regulated practice that accounts for a certain number of statements". Moreover, Ball explains $(2008,5)$ "Discourses mobilise truth claims and constitute rather than simply reflect social reality." By privileging certain information and ways of thinking, discourses transmit values, beliefs and ideologies through policy texts and influences from policy actors. Thus, the constitutive power of discourse is exercised in policy texts and interpretations of policy. By analysing changing discourses of policy texts over time, we can identify ideational change in policy constructs.

\section{The data set}

This article is drawn from a larger study investigating constructions of quality in Australian ECEC policy between 1972 and 2009. While the study has generated a large corpus of data, the data set utilised for the analysis reported here consists primarily of four policy documents underpinning the COAG reforms: New Directions for Early Childhood Education (Rudd and Macklin 2007a); Labor's Plan for High Quality Child Care (Rudd and Macklin 2007b); Towards a National Quality Framework for Early Childhood Education and Care (Department of Education, Employment and Workplace Relations 2009) and Investing in the Early Years: A National Early Childhood Development Strategy (Council of Australian Governments 2009) (for more detail, see Table 1). As key expressions of government policy and documents commissioned to inform government, collectively, these documents contribute to "the general domain of all statements" that express "regulated practice" (Foucault 1972, 90) and "truth claims" (Ball 2008, 5) for policy at the time of the COAG reforms.

The data set used in the analysis also includes excerpts from transcripts of individual interviews with three policy actors, referred to here as policy elites because of their high professional profiles and strategic positions within ECEC policy-making circles. These policy elites, referred to throughout by the use of pseudonyms, made reference to the COAG reforms in interviews undertaken for the study. Brief professional profiles of the elite policy informants are included in Table 1.

\section{Analytic processes}

In the first stage of the analysis reported here, the data set was refined to 236 excerpts from the four policy documents and 38 excerpts from the interview transcripts that 
Table 1 Policy documents analysed in this article and brief descriptions of policy elite informants

\begin{tabular}{|c|c|c|}
\hline \multicolumn{3}{|l|}{ Data set } \\
\hline Government policy documents & Type & Description \\
\hline $\begin{array}{l}\text { 1. New Directions for Early } \\
\text { Childhood Education } \\
\text { (Rudd and Macklin 2007a) }\end{array}$ & Government document & $\begin{array}{l}\text { A key document of the Rudd Government's } \\
\text { policy platform for ECEC, publicly available } \\
\text { from January } 2007 \text { prior to the Federal } \\
\text { election in November } 24,2007 \text {. }\end{array}$ \\
\hline $\begin{array}{l}\text { 2. Labor's Plan for High Quality } \\
\text { Child Care (Rudd and Macklin 2007b) }\end{array}$ & Government document & $\begin{array}{l}\text { A key document of the Rudd Government's } \\
\text { policy platform for ECEC, publicly available } \\
\text { from October } 2007 \text { prior to the Federal } \\
\text { election on November } 24,2007 \text {. }\end{array}$ \\
\hline $\begin{array}{l}\text { 3. Towards a National Quality } \\
\text { Framework for Early Childhood } \\
\text { Education and Care (Department } \\
\text { of Education, Employment and } \\
\text { Workplace Relations DEEWR 2009) }\end{array}$ & Discussion paper & $\begin{array}{l}\text { A commissioned paper designed to inform } \\
\text { government policy, January, } 2009 .\end{array}$ \\
\hline $\begin{array}{l}\text { 4. Investing in the Early Years: } \\
\text { A National Early Childhood } \\
\text { Development Strategy } \\
\text { (Department of Education, } \\
\text { Employment and Workplace } \\
\text { Relations DEEWR 2009) }\end{array}$ & Government document & $\begin{array}{l}\text { An expression of government policy that } \\
\text { formalised the COAG reform initiatives, } \\
\text { July } 2,2009 \text {. }\end{array}$ \\
\hline \multicolumn{3}{|l|}{$\begin{array}{l}\text { Transcripts from interviews } \\
\text { with policy elites }\end{array}$} \\
\hline 1. Avril & $\begin{array}{l}\text { In-depth individual } \\
\text { interview transcript }\end{array}$ & $\begin{array}{l}\text { A former senior policy advisor, academic } \\
\text { and current social commentator. }\end{array}$ \\
\hline 2. Barbara & $\begin{array}{l}\text { In-depth individual } \\
\text { interview transcript }\end{array}$ & $\begin{array}{l}\text { A former academic and Chief Executive } \\
\text { Officer of a large ECEC organisation and } \\
\text { current policy advisor involved in } \\
\text { policy-making circles during the } \\
\text { development of the COAG reforms. }\end{array}$ \\
\hline 3. Sarah & $\begin{array}{l}\text { In-depth individual } \\
\text { interview transcript }\end{array}$ & $\begin{array}{l}\text { A former senior bureaucrat and policy } \\
\text { advisor active in policy-making circles } \\
\text { during the development of the } \\
\text { COAG reforms. }\end{array}$ \\
\hline
\end{tabular}

referred to the term quality either implicitly or directly. Implicit references to the term quality included excerpts that referred to the importance of qualified staff for positive child outcomes while not necessarily referring specifically to the term quality. For example, "Recognised and up-to-date qualifications based on evidence will strengthen the care that is given to our children" (Rudd and Macklin 2007b, 7). Direct references to the term quality occurred 495 times in the four policy documents analysed. For example, "Quality in child care is in large part determined by the interaction between child care staff and the children in their care" (Rudd and Macklin 2007b, 6). After indentifying the excerpts, we drew first on a thematic approach to data analysis (Braun and Clarke 2006) as a preliminary means of managing the data. This approach involved repeated readings of the excerpts to identify patterns in references to quality (Logan et al. 2013). Identified patterns were assigned sub-themes. Multiple sub-themes were then clustered into common themes (for more detail, see Logan et al. 2013). The 'keyness' of a theme was not reliant on its frequency or quantifiable measures for the term quality but identified according to its relationship to the research question (Braun and Clarke 2006).

Second, we applied Bacchi's (2009) 'What's the problem represented to be?' approach to policy analysis. This approach uses six sequential questions, (see Appendix 2) to 
analyse how dominant discourses shape problems contained within policies. Adopting this discursive approach made it possible for us to identify how quality was shaped by particular discourses within the reforms.

In addition, drawing loosely on Hogan and Doyle's framework (2009), we identified macro-contextual factors influencing policy change in the Australian context. Macro-contextual factors such as references to social, economic or political dynamics were drawn from the data set and the research literature (see for example, Brennan and Adamson 2012; Elliott 2006; Organisation for Economic Co-operation and Development 2006; Press 2006; Press and Hayes 2000). These factors included, but were not limited to, a change of national Government, a global financial crisis (GFC) and the financial collapse Australia's largest child care corporation, ABC Learning (Sumsion 2012). Drawing on these factors enabled us to conceptualise elements of a critical juncture and consider the extent to which these elements are present in the COAG reforms.

\section{Will the COAG reforms prove to be a critical juncture in Australian ECEC policy?}

In order to address this question, we draw upon our extended conceptualisation of a critical juncture by identifying elements that coalesce at important historical moments. These elements refer to major policy change that occurs at politically unsettled times or crises, signals ideational and radical change (Hogan and Doyle 2009) and has lasting impact beyond one change of government (Donnelly and Hogan 2012). The presence of these elements may lead to fundamental policy change for systems and structures and potentially signal a critical juncture in Australian ECEC policy.

\section{Politically unsettled times}

Political instability may be connected to numerous events, such as electoral landslides or other conditions associated with social or economic upheavals (Hogan and Doyle 2009). The COAG reforms were introduced at a time of political and economic instability. In November 2007, the progressive Rudd Labor Government [2007-2010; 2013] defeated the conservative Howard Coalition Government [1996-2007] after 11 years in office. The Rudd Government victory was described as an historic electoral win that signified one of the biggest swings toward labour in 40 years (McKew 2013). However, within its first year in office, in September 2008, the GFC foreshadowed looming economic instability for Australia and impacted negatively on international economies.

Shortly after the onset of the GFC in November 2008, Australia's largest corporate child care provider, $\mathrm{ABC}$ Learning, experienced a financial collapse (Brennan and Adamson 2012). The collapse of $A B C$ Learning created uncertainties about child care arrangements and the ability to undertake paid employment for many families as the company provided child care for over 100,000 children and employed approximately 16,000 staff (Sumsion 2012). In an unprecedented move, the Australian Government spent \$22 million to 'bail out' the company until the end of December 2008 (Dunkerley and Draper 2008) prior to the eventual sale of over 650 ABC Learning Centres (Brennan and Adamson 2012). These events contributed to unsettled political and economic times. 


\section{Ideational and radical policy change}

The incoming Rudd Government promised ideational and radical policy change for the early childhood sector, underpinned by principles akin to social democracy (Rudd 2006). The rationale for this change was that improving quality in ECEC across all Australian jurisdictions would lead to positive and more equitable outcomes for children. Accordingly, the change of government and promises contained within the reforms also signified a new era by establishing intergovernmental agreement for nationally consistent policy measures aimed at unifying existing multi-layered administrative and regulatory arrangements (Cheeseman and Torr 2009). These government measures focused on balancing principles of the free market with increased levels of social responsibility.

\section{Lasting impact?}

The reforms were well received as a step forward for the early childhood sector (Cheeseman and Torr 2009; Tayler 2011). Yet policy developments that bring about ideational and radical change also rely on political commitment to sustain their lasting impact. Flottman and Page (2012), for example, identified how complex events and the presence of 'political will' in the years prior to the reforms led to the success of the Victorian State Government in providing leadership, under the auspice of the COAG reforms. In doing so, they highlight the importance of political will as a useful concept for understanding influences that bring about policy change. Their explanation is akin to Hogan and Doyle's (2009) explanation of the role of policy actors and political entrepreneurs, such as policy elites and elected politicians, as agents in bringing about ideational change. Therefore, Australia-wide improvements to quality in ECEC rely partly on political will to sustain the lasting impacts of the reforms.

Ball (1994) explains that policy is not only what is enacted but also what is intended. At the time of writing, the COAG reforms are partway through one change of government with the Abbott-led Coalition (Conservative) Government elected in September 7, 2013. Uncertainties associated with whether this Government will reinforce and strengthen the intended reforms or erode them by incremental policy change loom large. Preliminary statements in the Productivity Commission Issues Paper (Productivity Commission 2013, iii) indicate that the "Australian Government is committed to establishing a sustainable future for a more flexible, affordable and accessible child care and early childhood learning market." Subsequent, recommendations from the Productivity Commission's Draft Report into Childcare and Early Childhood Learning (Productivity Commission 2014) indicate a weakening of qualification requirements for educators working with children between birth and three years of age. If market-driven considerations of flexibility, affordability and accessibility overshadow considerations of quality, such as improving proportions of degree and diploma qualified staff for all children and ongoing support for teacher-child interactions, it is possible that quality in ECEC will be diminished. In turn, weakening provision of quality, particularly associated with pedagogical practices and educational programs, is likely to have deleterious effects on children as high-quality teacher-child instructional interactions are associated with children's positive academic and social outcomes (Mashburn et al. 2008). Moreover, these market-driven considerations would also undermine attempts to build the capacity of the early childhood workforce, thereby eroding the lasting impact of the reforms. 
In the following section, to deepen our understandings of ideational change underpinning the reforms and to assist in gauging the likelihood of the reforms having lasting impact, we examine how quality has been shaped by particular discourses. Whether or not the reforms will have lasting impact for how quality is constructed in future policy documents raises implications for the employment of qualified staff and increasing the proportion of degree and diploma-qualified staff in the early childhood workforce.

\section{Results and discussion}

\section{Constructions of quality in the COAG reforms}

As previously mentioned, the reforms focus on quality as a centrepiece of change to systems and structures for the early childhood sector (Cheeseman and Torr 2009; Logan et al. 2012). In the context of the reforms, the term quality is generally assumed to mean structures and practices that improve outcomes for children. For example, the reforms include a focus on "universal access" to quality in ECEC in the year before school, a "national quality agenda" and initiatives to improve the "quality and supply of the early childhood education and care workforce" (Council of Australian Governments 2009, 5). References to quality as a conduit for positive child outcomes give some prominence to children in government policy, rather than primarily focussing on workforce participation. While multiple discourses exist within policy documents underpinning the reforms, our analysis identified quality in ECEC as primarily constructed through discourses of investment in stronger standards and qualified staff.

\section{Discourses of investment in stronger standards}

Discourses of investment in stronger standards reflected recognition by policymakers that inconsistent standards and a patchwork of ECEC service provision can lead to uneven access to quality in ECEC for children. For example, the Strategy stated:

Quality standards vary across jurisdictions, sectors and service types. Existing arrangements for setting, assessing and monitoring quality in the early childhood sectors are fragmented and complex (Council of Australian Governments 2009, 18).

Uneven access to high-quality service provision was a concern as high-quality ECEC supports children's well-being and learning whereas poor quality does not (Camilli et al. 2010; Mashburn et al. 2008; Sylva et al. 2004). Similar concerns were also identified in commissioned reports to advise government policy. For instance, the Report of the Expert Advisory Panel on Quality Early Childhood Education and Care explained:

The lack of consistency is a cause for concern because evidence about the influence and impact of qualifications, group size and staff-child ratios indicate that the existing benchmarks in the various jurisdictions are unlikely to deliver the best possible outcomes for children (Department of Education, Employment and Workplace Relations 2009, 7).

By highlighting inconsistent standards and service provision, the reforms emphasised the need to redress inequities in ECEC. This was a well-intended policy move. Yet, an 
emphasis on stronger standards accentuates only one aspect of quality (Organisation for Economic Co-operation and Development 2006). The provision of high-quality ECEC also requires attention to the continuing professional and career development of staff, team building and service responsiveness to local contexts. It could be argued that for the reforms to prove a critical juncture, there would need to be tangible and sustained commitment to balancing systems that measure and monitor quality with systems that strengthen and resource quality. The importance of establishing this balance was reinforced by Sarah, a former senior bureaucrat and policy advisor active in policy-making circles during the development of the COAG reforms. Sarah explained:

I actually met with [Minister's name removed] a few weeks ago about the new system [the development of the NQF and National Quality Standards (NQS)] and he asked me what I thought was happening and what people were doing and one of the worries I've got is that we are too interested in weighing the cow, we are not interested in fattening it up and just weighing the cow won't fatten it... I said to him, we are spending way too many resources on weighing and measuring, and not enough resources on development... (Sarah, former senior bureaucrat and ECEC policy advisor)

Sarah's comments highlight her concerns about emphasising a need for stronger standards while overlooking other systems to develop quality in ECEC. Difficulties arise, however, when government approaches to funding are tied to standards and regulations that measure and monitor quality and not to the cost of tangible investments in quality, such as the employment and ongoing professional and career development of well-qualified staff (Brennan and Adamson 2014). Therefore, absorbing the costs of tangible investments in quality is challenging for ECEC services especially in the absence of ongoing funding mechanisms to support these costs. The importance of ongoing funding mechanisms that provide incentives to employ and retain more highly qualified staff was also evident in comments from Avril, a former policy advisor, academic and current social commentator. Avril reflected on policy changes that had removed funding mechanisms to support the employment of highly qualified staff in decades past and led primarily to a reliance on regulations and systems that measure and monitor quality. She explained:

... there was a contract [over two decades ago] between the government and the centre to provide the service ... which means [the Commonwealth Government] saw itself as [having] that relationship [with the service] and then [politician's name removed] got rid of it ... but it means there is now no relationship apart from a regulatory one between government and services. (Avril, former policy advisor, academic and current social commentator)

From this perspective, ongoing tangible investments to strengthen and resource provision of quality require re-establishing funding mechanisms between government and early childhood services that go beyond monitoring standards and regulations. This 
connection would contribute to sustaining the lasting impacts of the reforms in ECEC policy.

\section{Discourses of investment in qualified staff}

Discourses of investment in qualified staff emphasise the employment of increased numbers of qualified staff and the need to increase the proportion of highly qualified staff, such as degree qualified staff, in the early childhood workforce. While there is still some conflicting evidence about the contributions degree qualified staff make to provision of quality, see for example debates sparked by Early et al. (2007), internationally, there is considerable consensus that provision of quality is complex and highly qualified staff tend to contribute to high-quality ECEC provision (Goelman et al. 2006; Harrison et al. 2009; Sylva et al. 2004). Yet, with some notable exceptions (Wangmann 1991, 1995), historically, in Australian ECEC policy, an emphasis on women's workforce participation and the expansion of child care places has taken precedence over the provision of highly qualified staff (Logan et al. 2012).

Encouragingly, policy documents associated with the reforms explicitly signalled a need for a more highly qualified workforce in order to improve quality. One of the ways they did so was by drawing attention to the contributions of degreequalified early childhood educators to positive child outcomes. The following example is drawn from New Directions for Early Childhood Education, which states that:

... when a child participates in an early learning program under the supervision of a degree-qualified early childhood educator, the long term economic benefits of early childhood education are even greater (Rudd and Macklin 2007a, 9).

Furthermore, the Strategy explains, high staff qualifications are a crucial feature of quality as:

Key aspects of quality linked to positive child outcomes include higher qualifications of the early childhood professionals, lower child-to-staff ratios and a strong relationship between the child and a stable caregiver (Council of Australian Governments 2009, 35).

The attention to highly qualified staff, as identified by these examples, suggests that Australian ECEC policy was becoming more closely aligned with research about the determinants of high-quality ECEC (Brennan and Adamson 2014). Highly qualified staff, such as degree-qualified educators, tend to promote quality through their specialist knowledge of early childhood education and professional practices (Sylva et al. 2004) and create workplace cultures that support high-quality programs through the ongoing development of pedagogical practices and support for the professional learning of all staff (Ryan and Whitebook 2012).

Conversely, the reforms signalled the need for a more highly qualified workforce by accentuating concerns over the high proportion of unqualified and certificate qualified staff as high numbers of staff with low-level qualifications tend to be associated with 
poor child outcomes (Sylva et al. 2004). For example, Labor's Plan for High Quality Child Care noted:

one-third of the child care workforce does not hold any qualifications in children's services. Of those who do have children's services related qualifications, the national survey found that a diploma or advanced diploma was the most common, held by $31 \%$ of the workforce, followed by $19 \%$ of staff with a Certificate III or IV and $10 \%$ with bachelor's degree (Rudd and Macklin 2007b, 7).

High proportions of unqualified and certificate qualified staff signalled low levels of investment in the early childhood workforce. The reforms involved a planned investment of \$73.5 million over four years to raise qualifications of child care workers, including targets of one early childhood teacher for six hours per day at long day care (LDC) and preschool services operating 50 hours or more per week and licensed for 25 or more children (Australian Children's Education and Care Quality Authroity 2014). Despite the welcomed investment, this target fell considerably short of the contemporaneous target established by the New Zealand Government: that all teacher-led centre-based ECEC services ensure $50 \%$ of their required staff hold an early childhood teaching qualification (Ministry of Education n. d.). This comparison raises questions about arguments framed around affordability (see for example, the Productivity Commission Report 2013) given that Australia has a considerably higher gross domestic product (GDP) per capita than New Zealand (World Bank 2014) and therefore arguably better able to afford to invest in a highly qualified early childhood workforce. The sustainability of the reforms seems tenuous because of at least three challenges.

Challenges to sustaining the impact of the reforms First, maintaining a higher proportion of degree-qualified educators than was previously mandated under most state/ territory regulations creates tensions for employers/early childhood service providers as more highly qualified staff means higher salary expenses. Tensions surrounding issues of profitability and affordability are exacerbated in the Australian context as a high proportion of services operate as for-profit businesses (Sumsion 2012). If staff salaries are higher than employers can afford or are willing to pay, then high-quality programs may be difficult for employers/early childhood services to attain.

Second, in the context of the reforms, degree-qualified educators have increased leadership responsibilities, such as implementing the first national curriculum for ECEC, the EYLF. Degree-qualified educators often act as mentors to staff who are attaining or upgrading qualifications and encountering new reporting and curriculum requirements. Findings from the Effective Provision of Preschool Education (EPPE) project showed that staff with low-level qualifications improve their pedagogical practices when they work with qualified teachers (Sylva et al. 2003). Yet, these improvements may not be forthcoming if qualified teachers are not adequately supported in their mentoring of staff with low-level qualifications.

Third, requirements for a large proportion of unqualified or certificate qualified staff to attain higher qualifications raise expectations for these staff to increase their knowledge of discipline-based content and pedagogical practices (Grieshaber 2010). The 
importance of improved knowledge of pedagogical practices, such as intentional teaching and sustained shared thinking, was also emphasised by Barbara, a former Chief Executive Officer, academic and policy advisor. Barbara explained:

... concepts like intentional teaching [and] sustained [shared] thinking are really important for our profession that move it beyond ... well... we'll put out a few toys and be nice to the children and that's good enough... if you want a centre to work well your commitment to professional development and all those things is critical (Barbara, former Chief Executive Officer, academic and policy advisor).

Barbara's comments highlight that higher staff qualifications and dedication to ongoing professional development is necessary to support the implementation of highquality programs. Therefore, high proportions of staff gaining or upgrading qualifications require access to ongoing professional development if they are to enact new understandings of pedagogical practices in their work environments (Grieshaber 2010). The recently established Long Day Care Professional Development Programme (LDCPDP) supports early childhood educators in (LDC) services to meet qualification requirements in the NQF, but is a one-off injection of funds. Moreover, the program is available only to educators employed in LDC and not to educators employed in other kinds of early childhood services, such as preschools. If support for quality through the ongoing professional development and practices of more highly qualified staff is inadequate, then sustaining quality may be eroded.

Moreover, if the challenges raised in this section are not adequately addressed, the lasting impact of the reform's promises of improving quality in ECEC may dissipate and the potential for the reforms to constitute a critical juncture in ECEC policy may be lost. In the concluding section, we return to our speculations posed at the beginning of this article, concerning whether or not the reforms will prove to constitute a critical juncture in ECEC policy, particularly in relation to recent policy developments.

\section{Conclusions}

This article draws attention to a transformative shift that potentially constitutes a critical juncture in Australian ECEC policy. Yet our speculations, as to whether or not the reforms will constitute a critical juncture in ECEC policy are necessarily unresolved. Some intended that policy reforms have not yet been fully implemented, such as the complete implementation of the NQF, and while the Productivity Commission (2014) inquiry has concluded, the final report from the Government is not yet released. Hence, a key element in determining a critical juncture-lasting impact-is still open to conjecture.

Many of the Productivity Commission's draft recommendations emphasise the need for more flexible, affordable, accessible child care with the cost of improved standards being positioned as counter to these aims (Productivity Commission 2014). The Productivity Commission recommendations erode the policy emphases on quality by watering down reform requirements for stronger standards and highly qualified staff. However, overwhelming opposition by early childhood advocates and key stakeholders to the watering down of standards and staff qualifications, particularly in relation to qualification requirements for educators of children from birth 
to three years (Early Childhood Australia 2014) may deter government from acting on those recommendations, especially in the face of robust research evidence that quality is 'key' to a strong Australian ECEC system (for example, Brennan and Adamson 2014). Ultimately, sustaining the reforms and maintaining a quality agenda despite the Productivity Commission's recommendations will require political will and ongoing mobilisation by early childhood advocates, activists and professional organisations. A concerted effort to retain an emphasis on positive outcomes for children, however, may help to sustain ideational change and realise the potential for the reforms to have a lasting impact.

In conclusion, our speculations raise important matters about policy change for quality in ECEC. We contend that there is a need to draw attention to the complex contexts of policy production, illuminated by speculative studies of critical junctures, to ensure that provision of high quality in ECEC policy is sustainable and not subject to erosion through successive changes of government.

\section{Endnote}

${ }^{1}$ Long day care (LDC) refers to centre-based child care services which usually cater for children from birth to school age. These services are open for a minimum of $8 \mathrm{~h}$ per day, 5 days per week and operate for a minimum of 48 weeks per year (Press and Hayes 2000).

\section{Appendix 1: National reform initiatives of 'Investing in the Early Years-A National Early Childhood Development Strategy' (Council of Australian Governments 2009, 5)}

National reform initiatives that seek to improve early childhood outcomes include:

- a National Partnership Agreement on Early Childhood Education to achieve universal access to quality early childhood education for all children in the year before school by 2013

- a National Partnership Agreement on Indigenous Early Childhood Development to establish 35 new Children and Family Centres and to increase access to antenatal care, teenage sexual health and child and family health services for Indigenous children and families

- a six-year National Partnership Agreement on Preventive Health with a focus on strategies to prevent chronic diseases that commence in early childhood

- a national quality agenda for early childhood education and care which includes stronger standards, streamlined regulatory approaches, a rating system and an Early Years Learning Framework

- national workforce initiatives to improve the quality and supply of the early childhood education and care workforce

- the Closing the Gap initiative which includes ambitious targets for Indigenous children related to infant mortality, literacy and numeracy and participation in quality early childhood education

- a National Framework for Protecting Australia's Children

- the Melbourne Declaration on Educational Goals for Young Australians

- a National Family Support Program which brings together eight Commonwealth programs for children, families and parenting

- paid parental leave arrangements

- a National Plan to Reduce Violence against Women and Children

- development of an Early Intervention and Prevention Framework under the National Disability Agreement

- a National Partnership Agreement on Homelessness, with a focus on intervening early for children and their families at risk of homelessness. 


\title{
Appendix 2: What's the problem represented to be? An approach to policy analysis
}

1. What's the problem (e.g. the problem of uneven quality in ECEC) represented to be in a specific policy?

2. What presuppositions or assumptions underlie this representation of the problem?

3. How has this representation of the 'problem' come about?

4. What is left unproblematic in this problem representation? Where are the silences? Can the 'problem' be thought about differently?

5. What effects are produced by this representation of the 'problem'?

6. How/where has this representation of the 'problem' been produced, disseminated and defended? How could it be questioned, disrupted and replaced? (Bacchi 2009, 2).

Competing interests

The authors declare they have no competing interests - financial or non-financial.

\section{Authors' contributions}

$\mathrm{HL}$ was responsible for data collection, analysis and interpretation of the data and drafting the manuscript. Furthermore, HL has been involved in revising the manuscript critically and adding important intellectual content, particularly in relation to the conceptualisation of a critical juncture. JS and FP made contributions by revising the manuscript critically for structure, intellectual content and the development of the argument. All three authors agree to be accountable for all aspects of the work in regards to questions of accuracy and integrity for any part of the work. These aspects have been appropriately investigated and resolved. Moreover, each author has participated sufficiently in the work to take public responsibility for appropriate portions of the content. All authors read and approved the final manuscript.

\begin{abstract}
Authors' information
$\mathrm{HL}$ is a Lecturer in Early Childhood Education at Charles Sturt University where she is in the final stages of studies toward a PhD. Her doctoral studies focus on investigating quality in Australian early childhood education and care and policy between 1972 and 2009. This manuscript is fifth in a series of papers that comprise HL's doctoral studies to date. Her other research interests focus on historical policy analyses in early childhood education and care policy, leadership in early childhood and play. JS is the Foundation Professor of Early Childhood at Charles Sturt University and Director of the Research Institute of Professional Practice, Learning and Education (RIPPLE). She has long standing research interests in early childhood professional practice and policy, supported through funding from the Australian Research Council and other bodies. She is currently Co-Director of the Excellence in Early Years Education Collaborative Research Network (CRN). FP is an Associate Professor in Education at Charles Sturt University. She has written extensively on Australian Early Childhood Education and Care policy, including on the corporatisation of child care. She is currently involved in research on quality in early childhood programmes, infants' lives in child care, and integrated early childhood services.
\end{abstract}

Received: 8 August 2014 Accepted: 20 May 2015

Published online: 17 June 2015

\section{References}

Australian Children's Education and Care Quality Authroity (ACECQA). (2014). http://www.acecqa.gov.au/. Accessed 18 January 2015

Bacchi, C. (2009). Analysing policy: what's the problem represented to be? Frenchs Forest. Sydney: Pearson Education. Ball, SJ. (1994). Educational reform: a critical and poststructuralist approach. Buckingham: Open University Press.

Ball, SJ. (2008). The education debate. Bristol: The Policy Press.

Braun, V, \& Clarke, V. (2006). Using thematic analysis in psychology. Qualitative Research in Psychology, 3(2), 77-101. Brennan, D, \& Adamson, E. (2012). Early childhood education and care policy. In J Bowes, R Grace, \& K Hodge (Eds.), Children, families and communities (4th ed., pp. 255-270). Melbourne: Oxford University Press.

Brennan, D, \& Adamson, E. (2014). Financing the future: an equitable and sustainable approach to early childhood education and care. SPRC 01/14. Sydney: Social Policy Research Centre: University of New South Wales.

Camilli, G, Vargas, S, Ryan, S, Barnett, WS. (2010). Meta-analysis of the effects of early education interventions on cognitive and social development. The Teachers College Record, 112(3), 579-620.

Capoccia, G, \& Kelemen, RD. (2007). The study of critical junctures: theory, narrative, and counterfactuals in historical institutionalism. World Politics, 59(3), 341-369.

Cheeseman, S, \& Torr, J. (2009). From ideology to productivity: reforming early childhood education and care in Australia. International Journal of Child Care and Education Policy, 3(1), 61-74.

Council of Australian Governments. (2009). Investing in the early years: a national early childhood development strategy. https://www.coag.gov.au/sites/default/files/national_ECD_strategy.pdf. Accessed 16 June 2014. 
Department of Education, Employment and Workplace Relations (DEEWR). (2009). Towards a national quality framework for early childhood education and care (Report of the expert advisory panel on quality early childhood education and care). Canberra: Department of Education, Employment and Workplace Relations. http://www.baysidefamilydaycare.com/ EAP_report.pdf. Accessed 7 August 2014.

Donnelly, P, \& Hogan, J. (2012). Understanding policy change using a critical junctures theory in comparative context: the cases of Ireland and Sweden. Policy Studies Journal, 40(2), 324-350.

Dunkerley, S, \& Draper, M. (2008, November 7). Government commits \$22m to ABC Learning. The Sydney Morning Herald. http://www.smh.com.au/. Accessed 10 Feb 2014.

Early Childhood Australia (ECA). (2014). Response to the productivity commission's draft report on the inquiry into child care and early childhood learning. http://www.earlychildhoodaustralia.org.au/wp-content/uploads/2014/01/ECAResponse-to-PCI-Draft-Report_FINAL.pdf. Accessed 20 January 2015.

Early, DM, Maxwell, KL, Burchinal, M, Bender, RH, Ebanks, C, Henry, GT, et al. (2007). Teachers' education, classroom quality, and young children's academic skills: results from seven studies of preschool programs. Child Development, 78(2), 558-580.

Elliott, A. (2006). Early childhood education: pathways to quality and equity for all children. Australian Education Review. Melbourne: Australian Council for Educational Review.

Flottman, R, \& Page, J. (2012). Getting early childhood onto the reform agenda: an Australian case study. International Journal of Child Care and Education Policy, 6(1), 17-33.

Foucault, M. (1972). The archaeology of knowledge. London: Routledge.

Foucault, M. (2000). Power. In JD Faubion (Ed.), Essential works of Foucault, 1954-1984 (Vol. 3, pp. 223-238). New York: The New Press.

Gal, J, \& Bargal, D. (2002). Critical junctures, labor movements and the development of occupational welfare in Israel. Social Problems, 49(3), 432-454.

Goelman, H, Forer, B, Kershaw, P, Doherty, G, Lero, D, \& LaGrange, A. (2006). Towards a predictive model of quality in Canadian child care centers. Early Childhood Research Quarterly, 21, 280-295.

Grieshaber, S. (2010). Departures from tradition: the early years learning framework for Australia. International Journal of Child Care and Education Policy, 4(2), 33-44.

Hall, P. (1993). Policy paradigms, social learning, and the state: the case of economic policymaking in Britain. Comparative politics, 25(3), 275-296.

Harrison, L, Ungerer, J, Smith, G, Zubrick, S, Wise, S, Press, F, \& Waniganayake, M. (2009). Child care and early education in Australia: the longitudinal study of Australian children. Canberra: Department of Families, Housing, Community Services and Indigenous Affairs.

Hogan, J, \& Doyle, D. (2007). The importance of ideas: an a priori critical juncture framework. Canadian Journal of Political Science, 40(4), 883-910.

Hogan, J, \& Doyle, D. (2009). A comparative framework: how broadly applicable is a 'rigorous' critical junctures framework? Acta Politica, 44(2), 211-240.

Logan, H, Press, F, \& Sumsion, J. (2012). The quality imperative: Tracing the rise of 'quality' in Australian early childhood education and care policy. Australasian Journal of Early Childhood, 37(3), 4-13.

Logan, H, Sumsion, J, \& Press, F. (2013). The Child Care Act 1972: A critical juncture in Australian ECEC and the emergence of 'quality'. Australasian Journal of Early Childhood, 38(4), 84-91.

Mashburn, AJ, Pianta, RC, Hamre, BK, Downer, JT, Barbarin, O, Bryant, D, \& Howes, C. (2008). Measures of classroom quality in prekindergarten and children's development of academic, language, and social Skills. Child Development, 79(3), 732-749.

McKew, M. (2013). Tales from the political trenches. Melbourne: Melbourne University Publishing.

Ministry of education (n d.). http://www.lead.ece.govt.nz/ManagementInformation/RegulatoryFrameworkForECEServices.aspx Accessed 5 August 2014

Organisation for Economic Co-operation and Development. (2012). Starting strong III: a quality toolbox for early childhood education and care. Paris: OECD.

Organisation for Economic Co-operation and Development (OECD). (2006). Starting strong Il; early childhood education and care. Paris: OECD.

Pierson, P. (2004). Politics in time: history, institutions and social analysis. New Jersey: Princeton University Press.

Press, F. (2006). What about the kids. Policy directions for improving the experiences of infants and young children in a changing world. Sydney: NiFTEY, NSW and Qld Children's Commission.

Press, F, \& Hayes, A. (2000). OECD thematic review of early childhood education and care policy, Australian background report. Canberra: (Department of Education, Training and Youth Affairs: AGPS).

Productivity Commission. (2013). Childcare and early childhood learning. Canberra: Issues Paper.

Productivity Commission. (2014). Childcare and early childhood learning. Canberra: Draft Report.

Rudd, K. (2006). Howard's brutopia: the battle of ideas in Australian politics. The Monthly, 18(November), 46-50.

Rudd, K, \& Macklin, J. (2007a). New directions for early childhood education: universal access to early learning for 4 year olds. Canberra: Australian Labor Party.

Rudd, K, \& Macklin, J. (2007b). Labor's plan for high quality child care. http://parlinfo.aph.gov.au/parllnfo/download/ library/partypol/ERPO6/upload_binary/erpo64.pdf;fileType=application\%2Fpdf\#search=\%22library/partypol/ ERPO6\%22 Accessed 10 Feb 2014.

Ryan, S, \& Whitebook, M (Eds.). (2012). More than teachers: the early care and education workforce. New York: Guilford Press.

Sumsion, J. (2012). ABC Learning and Australian early education and care: a retrospective ethical audit of a radical experiment. In E Lloyd \& H Penn (Eds.), Childcare markets local and global: can they deliver an equitable service? (pp. 209-225). Bristol: Policy Press.

Sylva, K, Melhuish, E, Sammons, P, Siraj-Blatchford, I, Taggart, B, \& Elliot, K. (2003). The effective provision of pre-school education (EPPE) project: findings from the pre-school period. (Research Brief No. RBX15-03). London: Department for Education and Skills.

Sylva, K, Melhuish, E, Sammons, P, Siraj-Blatchford, I, \& Taggart, B. (2004). The effective provision of pre-school education (EPPE) project: final report: a longitudinal study funded by the DfES 1997-2004. London: Institute of Education, University of London. 
Tayler, C. (2011). Changing policy, changing culture: steps toward early learning quality improvement in Australia. International Journal of Early Childhood, 43(3), 211-225.

United Nations International Children's Emergency Fund (UNICEF). (2008). Innocenti report card 8: the child care transition. Florence: UNICEF Innocenti Research Centre.

Wangmann, J. (1991). Accreditation of early childhood services in Australia. A report to the Department of Health, Housing and Community Services. Canberra: Department of Health, Housing \& Community Services.

Wangmann, J. (1995). Towards integration and quality assurance in children's services. Melbourne: Australian Institute of Family Studies.

World Bank. (2014). GDP per capita. http://data.worldbank.org/indicator/NY.GDP.PCAP.CD Accessed 22 July 2014.

Submit your manuscript to a SpringerOpen ${ }^{\circ}$ journal and benefit from:

- Convenient online submission

- Rigorous peer review

- Immediate publication on acceptance

- Open access: articles freely available online

- High visibility within the field

- Retaining the copyright to your article

Submit your next manuscript at $>$ springeropen.com 